Manuscript Number:

Title: Palladium-ceria nanocatalyst for hydrogen oxidation in alkaline media: optimization of the $\mathrm{Pd}-\mathrm{CeO} 2$ interface

Article Type: Short communication

Keywords: hydrogen oxidation reaction; anion exchange membrane fuel cell; palladium; ceria; reactive spray deposition technology

Corresponding Author: Dr. Haoran Yu, Ph.D.

Corresponding Author's Institution: University of Connecticut

First Author: Haoran Yu, Ph.D.

Order of Authors: Haoran Yu, Ph.D.; Elena S Davydova, Ph.D.; Uri Ash; Hamish A Miller, Ph.D.; Leonard J Bonville; Dario R Dekel, Ph.D.; Radenka Maric, Ph.D.

Abstract: The development of Pt-free catalyst for anion exchange membrane fuel cells is limited by the sluggish hydrogen oxidation reaction (HOR) at the anode. Previously, the use of $\mathrm{CeO} 2$ as a catalyst promoter facilitated drastic ennoblement of Pd for the HOR kinetics in base media. However, further optimization and understanding of the $\mathrm{Pd}-\mathrm{CeO} 2$ interaction, surface properties, and its influence on HOR are still needed. In this work, three types of $\mathrm{Pd}-\mathrm{CeO} / \mathrm{C}$ catalysts are synthesized by a flame-based process, where the Pd-CeO2 interface and HOR activity are improved as compared to catalysts prepared by wet-chemistry processes. The correlation between the $\mathrm{Pd}-\mathrm{CeO} 2$ interaction and HOR activity is established through comparisons with the three types of $\mathrm{Pd}-$ $\mathrm{CeO} / \mathrm{C}$ synthesized catalysts using electrochemical techniques and $\mathrm{X}$-ray photoelectron spectroscopy. 
Dear Editor,

We would like to submit "Palladium-ceria nanocatalyst for hydrogen oxidation in alkaline media: optimization of the $\mathrm{Pd}-\mathrm{CeO}_{2}$ interface" to Nano Energy as a short communication paper. In this work we employed reactive spray deposition technology (RSDT) to optimize the design of $\mathrm{Pd}-\mathrm{CeO}_{2} / \mathrm{C}$ catalyst for hydrogen oxidation reaction (HOR) in alkaline media. Three types of $\mathrm{Pd}-\mathrm{CeO}_{2} / \mathrm{C}$ catalysts are developed and compared with the state-of-the-art $\mathrm{Pd}-\mathrm{CeO}_{2} / \mathrm{C}$ catalyst prepared by wet chemistry approach. With RSDT-derived $\mathrm{Pd}-\mathrm{CeO}_{2} / \mathrm{C}$ catalyst, the $\mathrm{Pd}-\mathrm{CeO}_{2}$ interaction is enhanced and the $\mathrm{HOR}$ activity out-performs the state-of-the-art catalyst. The RSDT process demonstrates great potential for tuning the interfacial structure of the catalyst and optimizing the catalytic activity.

I would like to state that the manuscript, or its contents in some other form, has not been submitted previously to Nano Energy and has not been published previously by any of the authors and/or is not under consideration for publication in another journal at the time of submission. The submission is approved by all authors and the host institution.

Thank you for reviewing.

Yours sincerely,

Haoran Yu, Ph.D.

Center for Clean Energy Engineering

University of Connecticut

44 Weaver Road, Unit 5233, Storrs, CT, 06269

Email: haoran.yu@uconn.edu

Radenka Maric, Ph.D.

Vice President for Research

UConn/UConn Health

Professor in Sustainable Energy

438 Whitney Road Ext., Unit 1006

Storrs, CT 06269

Storrs: 860.486.3621

Email: radenka.maric@uconn.edu

Dario Dekel, Ph.D.

Associate Professor,

The Wolfson Department of Chemical Engineering,

Technion - Israel Institute of Technology,

Haifa 3200003, Israel

Phone: 0778871792

Email:dario@technion.ac.il 


\title{
Palladium-ceria nanocatalyst for hydrogen oxidation in alkaline media: optimization of the $\mathrm{Pd}-\mathrm{CeO}_{2}$ interface
}

\author{
Haoran $\mathrm{Yu}^{1,2}$, Elena S. Davydova ${ }^{3,4}$, Uri Ash ${ }^{3}$, Hamish A. Miller ${ }^{5}$, Leonard Bonville ${ }^{2}$, Dario R. Dekel, ${ }^{3,4, *}$, \\ and Radenka Maric ${ }^{1,2, *}$. \\ ${ }^{1}$ Department of Chemical Engineering and ${ }^{2}$ Center for Clean Energy Engineering, University of \\ Connecticut, Storrs, 06226, CT, USA \\ ${ }^{3}$ The Wolfson Department of Chemical Engineering and ${ }^{4}$ the Nancy \& Stephan Grand Technion Energy \\ Program (GTEP), Technion - Israel Institute of Technology, Haifa 3200003, Israel \\ ${ }^{5}$ Istituto di Chimica dei Composti Organometallici (CNR-ICCOM), via Madonna del Piano 10, 50019 \\ Sesto Fiorentino, Firenze, Italy
}

\section{Research highlights:}

Flame-based RSDT process is used to optimize $\mathrm{Pd}-\mathrm{CeO}_{2} / \mathrm{C}$ catalyst design.

$\mathrm{Pd}-\mathrm{CeO}_{2} / \mathrm{C}$ catalysts shows improved $\mathrm{Pd}-\mathrm{CeO}_{2}$ interface.

Type 1 and 2 catalyst exhibits higher $\mathrm{HOR}$ activity than the state-of-the-art $\mathrm{Pd}-\mathrm{CeO}_{2} / \mathrm{C}$ catalysts. 


\title{
Palladium-ceria nanocatalyst for hydrogen oxidation in alkaline media: optimization of the $\mathrm{Pd}-\mathrm{CeO}_{2}$ interface
}

\author{
Haoran $\mathrm{Yu}^{1,2}$, Elena S. Davydova ${ }^{3,4}$, Uri Ash ${ }^{3}$, Hamish A. Miller ${ }^{5}$, Leonard Bonville ${ }^{2}$, Dario R. Dekel, ${ }^{3,4, *}$, \\ and Radenka Maric ${ }^{1,2, *}$. \\ ${ }^{1}$ Department of Chemical Engineering and ${ }^{2}$ Center for Clean Energy Engineering, University of \\ Connecticut, Storrs, 06226, CT, USA \\ ${ }^{3}$ The Wolfson Department of Chemical Engineering and ${ }^{4}$ the Nancy \& Stephan Grand Technion Energy \\ Program (GTEP), Technion - Israel Institute of Technology, Haifa 3200003, Israel \\ ${ }^{5}$ Istituto di Chimica dei Composti Organometallici (CNR-ICCOM), via Madonna del Piano 10, 50019 \\ Sesto Fiorentino, Firenze, Italy
}

\begin{abstract}
The development of Pt-free catalyst for anion exchange membrane fuel cells is limited by the sluggish hydrogen oxidation reaction (HOR) at the anode. Previously, the use of $\mathrm{CeO}_{2}$ as a catalyst promoter facilitated drastic ennoblement of Pd for the HOR kinetics in base media. However, further optimization and understanding of the $\mathrm{Pd}-\mathrm{CeO}_{2}$ interaction, surface properties, and their influence on $\mathrm{HOR}$ are still needed. In this work, three types of $\mathrm{Pd}-\mathrm{CeO}_{2} / \mathrm{C}$ catalysts are synthesized by a flame-based process, where the $\mathrm{Pd}-\mathrm{CeO}_{2}$ interface and the HOR activity are improved as compared to catalysts prepared by wetchemistry processes. The correlation between the $\mathrm{Pd}-\mathrm{CeO}_{2}$ interaction and the $\mathrm{HOR}$ activity is established through comparisons of three types of $\mathrm{Pd}-\mathrm{CeO}_{2} / \mathrm{C}$ synthesized catalysts using electrochemical techniques and X-ray photoelectron spectroscopy.
\end{abstract}

Key words: hydrogen oxidation reaction, anion exchange membrane fuel cell, palladium, ceria, reactive spray deposition technology

\section{Introduction}

Recently, a significant advancement has been achieved in the development of $\mathrm{H}_{2}$-based AEMFCs [1-4]. Further advancement in the AEMFC technology has been shown to be limited by carbonation issues during fuel cell operation [5-8], and by progress in the development of the key fuel cell components such as stable anion exchange membranes [9-12], as well as anode electrocatalysts [13]. In spite of the recent interest in Ni-based catalysts [14-17], the most advanced anode electrocatalysts currently available for AEMFCs are mainly based on platinum-group metals (PGMs). However, among PGMs, Pd shows the lowest catalytic activity for HOR in alkaline media: ca. $0.04-0.09 \mathrm{~mA} \mathrm{~cm}{ }_{\mathrm{Pd}}^{-2}$ for commercial $\mathrm{Pd} / \mathrm{C}$ nanoparticles [18-20] vs. ca. $0.6 \mathrm{~mA} \mathrm{~cm}_{\mathrm{Pt}}^{-2}$ for commercial Pt/C catalysts [19-22]. Significant promotion of the HOR electrocatalysis on Pd-based materials has been achieved with the use of Pd-coated $\mathrm{Cu}$ nanowires[23], Pd-decorated $\mathrm{Ru}$ nanotubes [24], as well as by doping with $\mathrm{Ni}$ [25,26], Ir [27], and $\mathrm{CeO}_{2}$ $[28,29]$. Among them, $\mathrm{Pd}-\mathrm{CeO}_{2}$ catalyst has shown the highest anode performance so far reported for Ptfree-based AEMFCs [30].

Ceria $\left(\mathrm{CeO}_{2}\right)$ is a well-known catalytic material, sometimes also used as a catalyst support [31]. In electrocatalysis, ceria has been employed in direct alcohol fuel cells due to its ability to promote the oxidation of the catalyst poisoning carbon monoxide produced in alcohol oxidation reactions [32-35]. It has been hypothesized that ceria promotes the formation of $\mathrm{Pd}-\mathrm{OH}_{\mathrm{ad}}$ species which facilitates ethanol oxidation kinetics [35]. The catalytic activity of Pt nanoparticles towards methanol electrooxidation in alkaline media has been demonstrated to be dependent on their interactions with the nanostructured ceria support [36]. Strong metal-support interactions between Pt and ceria have been postulated to induce preferential oxidation of $\mathrm{Pt}$ and consequently decrease the catalytic activity [36]. On the other hand, the 
use of $\mathrm{CeO}_{2}$ in Pd-based electrocatalysts on the anode of $\mathrm{H}_{2}$-AEMFC has led a 5-fold improvement of power density compared to the undoped $\mathrm{Pd} / \mathrm{C}$ [28]. The catalytic promotion of the HOR kinetics of the $\mathrm{Pd}-\mathrm{CeO}_{2} / \mathrm{C}$ composite was ascribed to the $\mathrm{OH}^{-}$donor effect of $\mathrm{CeO}_{2}$ [28]. Furthermore, $\mathrm{CeO}_{2}$ could stabilize the surface $\mathrm{PdO}$ species [37], which has been shown to promote the HOR kinetics on Pd [38]. In any case, the most prominent catalytic promotion might be achieved solely due to the optimal $\mathrm{Pd}-\mathrm{CeO}_{2}$ interface design [35]. Although the positive catalytic effect of ceria on the electrocatalytic activity of the metal-ceria composite has clear experimental evidence, the knowledge about the optimal metal-ceria interface is still lacking.

In the present work, $\mathrm{Pd}-\mathrm{CeO}_{2} / \mathrm{C}$ composite electrocatalysts are synthesized using three different synthetic approaches based on the flame-based reactive spray deposition technology (RSDT) as a flexible technique enabling to regulate of the particle sizes and providing more instruments to optimize the $\mathrm{Pd}-\mathrm{CeO}_{2}$ interface. The effect of the synthetic approach on the $\mathrm{Pd}-\mathrm{CeO}_{2}$ interaction is studied combining microscopic, spectral and electrochemical methods. The role of $\mathrm{Pd}-\mathrm{CeO}_{2}$ interaction in the improvement of the HOR catalytic activity is discussed and the ways for further advancement are anticipated.

\section{Experimental}

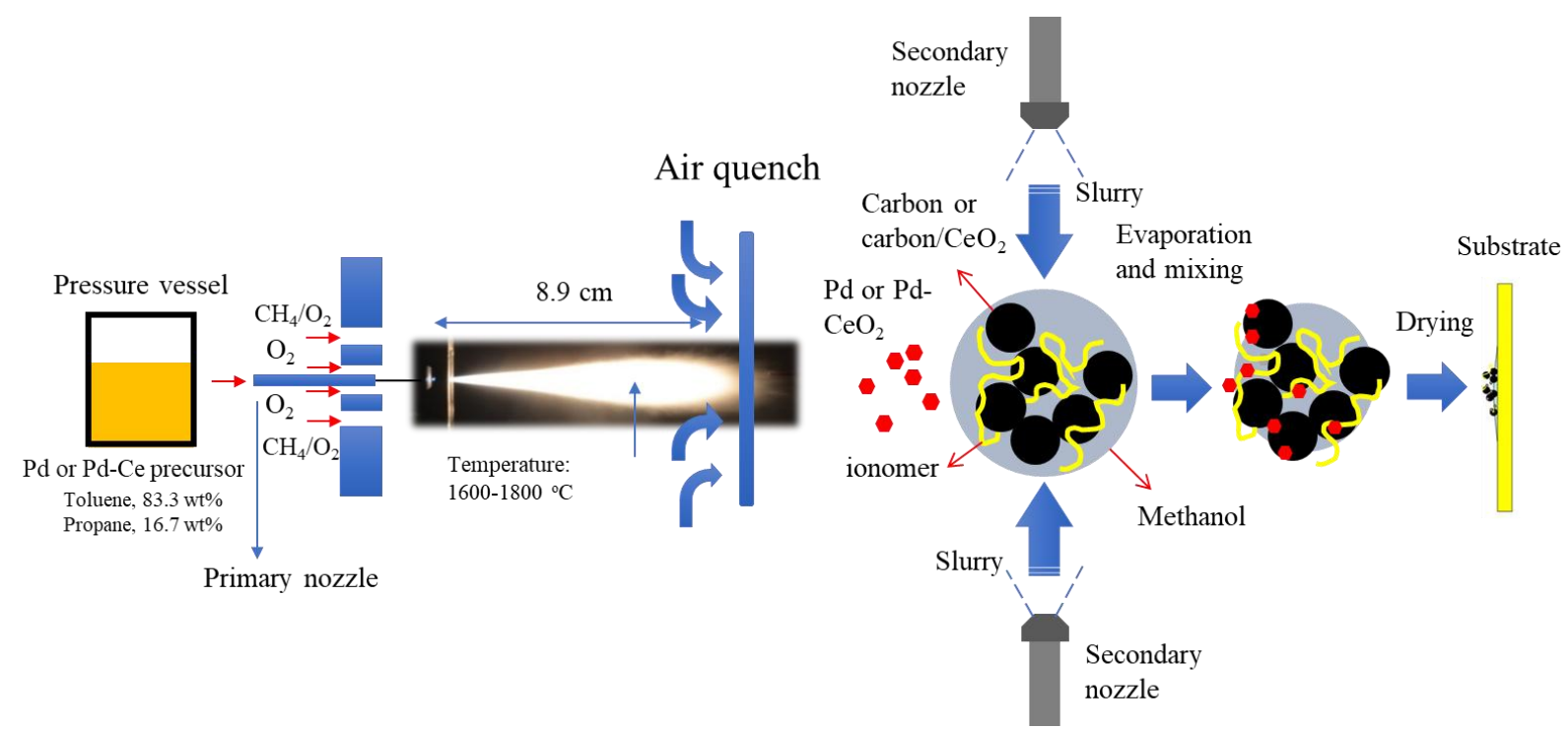

Figure 1. Schematic diagram of RSDT process for the synthesis of $\mathrm{Pd}-\mathrm{CeO}_{2} / \mathrm{C}$ catalysts.

\subsection{Catalysts synthesis}

A general schematic diagram of the RSDT process is shown in Figure 1. In this work, three types of Pd$\mathrm{CeO}_{2} / \mathrm{C}$ catalysts were synthesized using RSDT process (Figure 2). For the catalyst Type 1, the mixture of $\mathrm{Pd}$ precursor (Pd-2, 4-pentanedionate, Colonial Metals, Inc.) and $\mathrm{Ce}$ precursor (Cerium (III)-2ethylhaxonate, Alfa Aesar) solutions was sprayed through the primary nozzle to form $\mathrm{Pd}-\mathrm{CeO}_{2}$ nanoparticles. The carbon slurry consists of Vulcan XC-72R carbon black (Cabot Corp.) and Nafion® ionomer (5 wt\% $1100 \mathrm{EW}$, Dupont) with an ionomer-to-carbon weight ratio of 0.15 was sprayed from the secondary nozzles (Figure 1). For Type 2 and 3 catalysts, Pd precursor is sprayed from the primary nozzle to produce $\mathrm{Pd}$ nanoparticles in flame. The slurries of commercial $\mathrm{CeO}_{2}$ nanoparticles are introduced from the secondary nozzles. For Type 2 the particle size of $\mathrm{CeO}_{2}$ (Sigma Aldrich) is about $25 \mathrm{~nm}$ (Figure 2, Type 1), whereas for Type 3 the $\mathrm{CeO}_{2}$ (Cerion Advanced Materials, LLC.) has an average diameter of 5 nm (Figure 2, Type 3). The catalyst particles and support materials are mixed during flight before being deposited on the substrate. Detailed description of the RSDT process can be found in the supplementary materials and in previous publications [39-44]. The $\mathrm{Pd}-\mathrm{CeO}_{2} / \mathrm{C}$ catalysts were directly deposited onto 
glassy carbon electrodes (ACE6DC050GC, Pine Instruments) for electrochemical measurements. The resulting Pd and Ce loading are summarized in Table S2.

2.2 Physical and electrochemical characterizations:

The morphology and elemental distribution of the catalysts were characterized with scanning transmission electron microscopy (STEM) and X-ray energy-dispersive spectroscopy (XEDS). The TEM specimens were prepared by scrapping off the as-deposited thin film from a Teflon substrate. The scrapped-off powder was sonicated in ethanol for $30 \mathrm{~min}$ and pipetted on to a $\mathrm{Cu}$ TEM grid (Pacific grid, $\mathrm{Cu}-300 \mathrm{HD}$ ). Then, the TEM grid was dried under ambient air at room temperature for $12 \mathrm{~h}$. High-angle annular dark field (HAADF) images and elemental mapping are recorded at $200 \mathrm{kV}$ using Talos F200X TEM (Thermo Fisher Scientific). The XEDS spectrum and elemental maps are analyzed using Bruker Espirit software.

Catalyst structure and surface oxidation state were characterized by X-ray photoelectron spectroscopy (XPS) using a Phi $510 \mathrm{X}$-ray photoelectron Spectrometer (radiation source: Al Ka, $\lambda=1486.6 \mathrm{eV}$ ). The binding energies reported in this study were charge-corrected to obtain the adventitious carbon 1s binding energy of $284.8 \mathrm{eV}$.

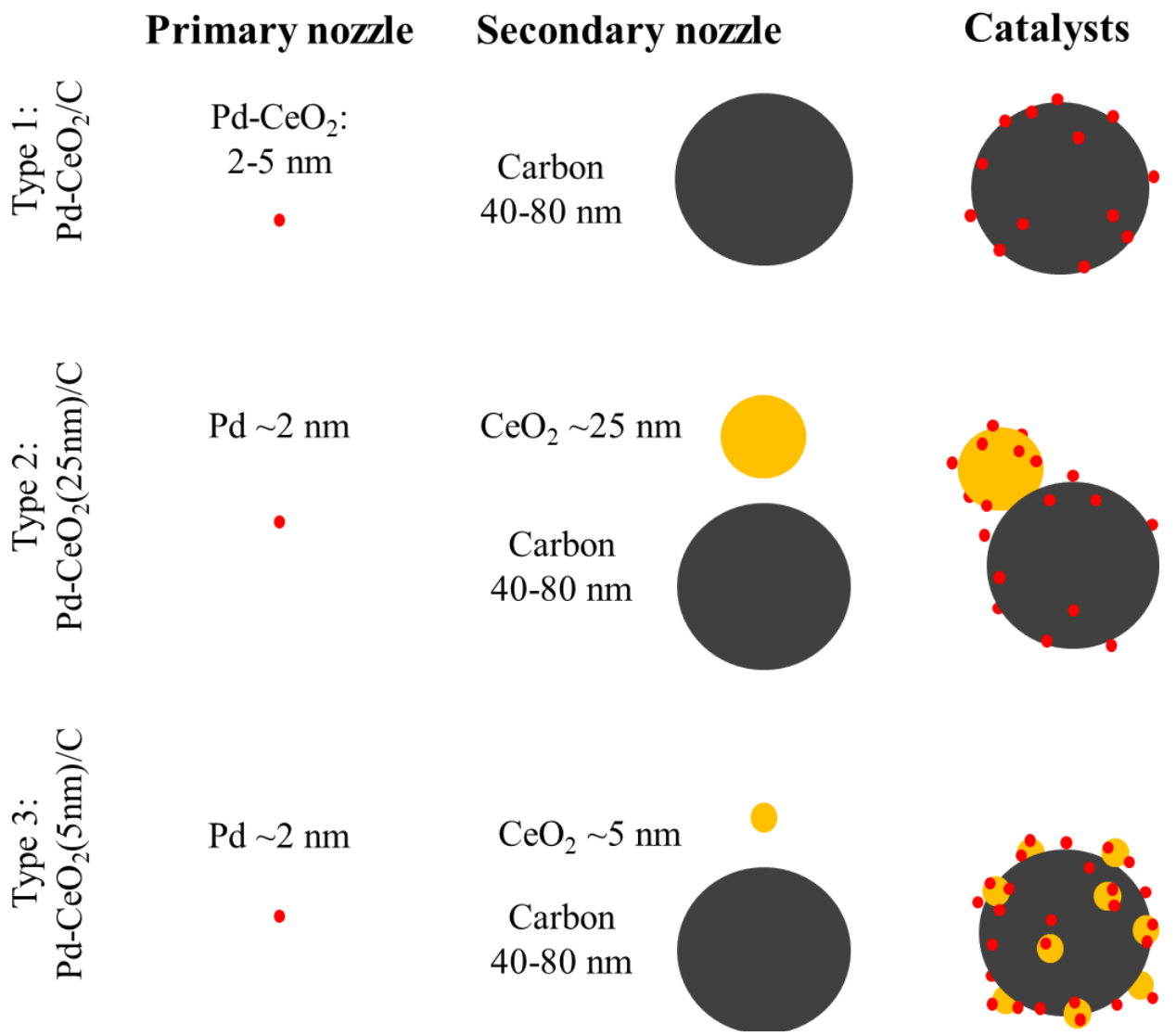

Figure 2. Schematic diagram of three types of $\mathrm{Pd}-\mathrm{CeO}_{2} / \mathrm{C}$ catalysts synthesized using RSDT process.

The catalyst loadings were analyzed with inductively coupled plasma optical emission spectroscopy (ICPOES) (Perkin Elmer Optima 7300DV) using a piece of catalyst thin film deposited on polypropylene membrane. The membrane was deposited simultaneously with the glassy carbon electrodes and the catalyst loading on the membrane was considered the same as that on the electrodes. 
Electrochemical measurements were conducted using a custom designed Teflon cell ( $250 \mathrm{~mL}$ volume). Sodium hydroxide (Sigma Aldrich, $99.99 \%$ trace metal grade) at $0.1 \mathrm{M}$ concentration was used as the electrolyte and $200 \mathrm{~mL}$ of electrolyte was added to the Teflon cell. The potential of the working electrode was determined using $\mathrm{Hg} / \mathrm{HgO}$ reference electrode with a potential of $0.92 \mathrm{~V}$ vs. RHE. Pt wire $(\mathrm{CH}$ Instruments) was used as the counter electrode. The working electrode (glassy carbon electrodes) was mounted on an electrode rotator (AFMSRCE, Pine Instruments). A Solartron 1287 potentiostat was used for all measurements. All measurements were performed at room temperature $\left(25-30^{\circ} \mathrm{C}\right)$. Prior to the measurement, the working electrode underwent electrochemical cleaning by cycling between $0.0 \mathrm{~V}$ and $1.4 \mathrm{~V}$ (vs. RHE) at a scan rate of $200 \mathrm{mV} \mathrm{s}^{-1}$ for 40 cycles. Cyclic voltammograms (CVs) were collected in $\mathrm{N}_{2}$-purged cell between $0.0 \mathrm{~V}$ and $1.4 \mathrm{~V}$ (vs. RHE) at a scan rate of $50 \mathrm{mV} \mathrm{s}^{-1}$ for 30 cycles until the $\mathrm{CV}$ was repeatable. The last cycle was reported. The polarization curve for $\mathrm{HOR}$ were recorded in $\mathrm{H}_{2}{ }^{-}$ purged $0.1 \mathrm{M} \mathrm{NaOH}$ from $-0.1 \mathrm{~V}$ to $1.0 \mathrm{~V}$ (vs. RHE) with a rotation speed of $1600 \mathrm{rpm}$ and a scan rate of $10 \mathrm{mV} \mathrm{s}^{-1}$.

\section{Results and discussions}

The distribution of $\mathrm{Pd}, \mathrm{Ce}$ and carbon species in all the three types of catalysts is illustrated using STEM and XEDS mapping (Figure 3). The HAADF images in Figure 3 show distinctive $\mathrm{Z}$ contrast as $\mathrm{Pd}$ and $\mathrm{Ce}$ have much higher atomic number than carbon. In Type 1, $\mathrm{Pd}-\mathrm{CeO}_{2}$ particles appear as small (2-5 nm) and highly agglomerated particles distributed on the surface of carbon particles. In the overlapped element map (Figure 3), the prevailing red (Pd) and the green (Ce) pixels suggest that the distribution of Pd and $\mathrm{CeO}_{2}$ phases in Type 1 catalysts is the most homogeneous, compared to Types 2 and 3. The Type 2 catalyst shows a different morphology where the $\mathrm{CeO}_{2}$ phase is comprised of large particles (in a broad range of 10-100 $\mathrm{nm}$ diameters) and are in contact with carbon particles. According to the element mapping of Type 2 catalyst (Figure 3), $\mathrm{Pd}$ is partially homogeneously distributed on the surface of $\mathrm{CeO}_{2}$ particles, however due to the lower dispersity of $\mathrm{CeO}_{2}, \mathrm{Pd}$ tends to segregate in bigger Pd-rich particles (red pixels, Figure 3). This must negatively affect the $\mathrm{Pd}-\mathrm{CeO}_{2}$ interface and decrease the effective interface area. Type 3 catalysts show that $\mathrm{CeO}_{2}$ distribution clearly follows the contours of the carbon black, since a small $\mathrm{CeO}_{2}$ nanoparticle $(5 \mathrm{~nm})$ is used. However, the surface of carbon is not fully covered with $\mathrm{CeO}_{2}$ particles and some of Pd particles are not in contact with $\mathrm{CeO}_{2}$ particles (Figure 3, Type 3). Comparing to previous works on $\mathrm{Pd}-\mathrm{CeO}_{2} / \mathrm{C}$ catalysts $[28,29]$, the RSDT process improves the mixing and interface between $\mathrm{Pd}$ and Ce with all three types of catalysts. It is hypothesized that Type 1 catalysts have more homogeneous co-distribution of $\mathrm{Pd}$ and $\mathrm{CeO}_{2}$ phases, with smaller particle sizes compared to Type 2 and 3. Therefore, in case of Type 1 catalysts, we would expect the most prominent chemical interaction between $\mathrm{Pd}$ and $\mathrm{CeO}_{2}$ and the highest catalytic activity for HOR. To reveal the possible chemical interaction between $\mathrm{Pd}$ and $\mathrm{CeO}_{2}$, XPS measurements were carried out. 

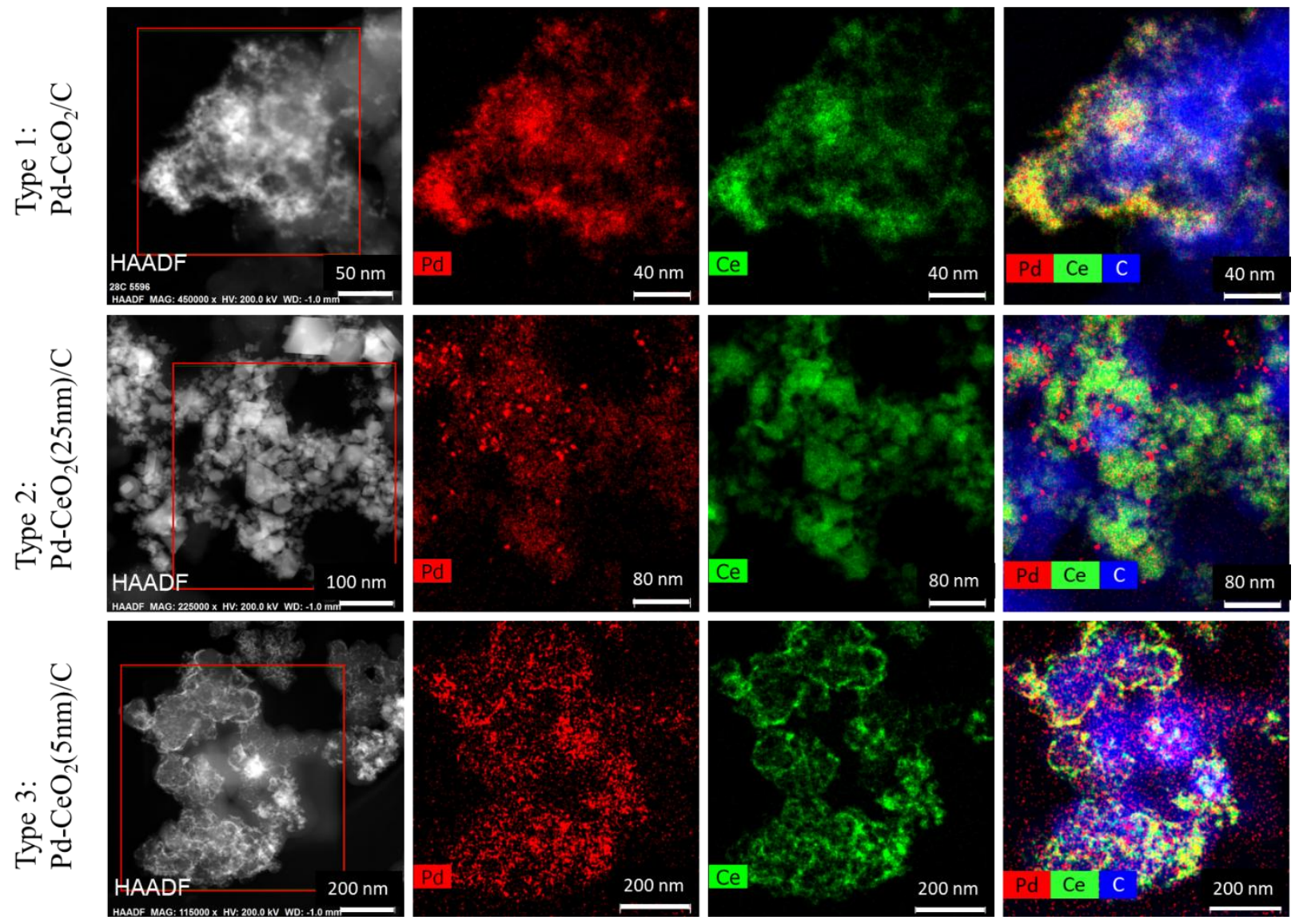

Figure 3. HAADF images and elemental mapping of three types of $\mathrm{Pd}-\mathrm{CeO}_{2} / \mathrm{C}$ catalysts using XEDS. The elemental maps correspond to the square region in the HAADF images. 

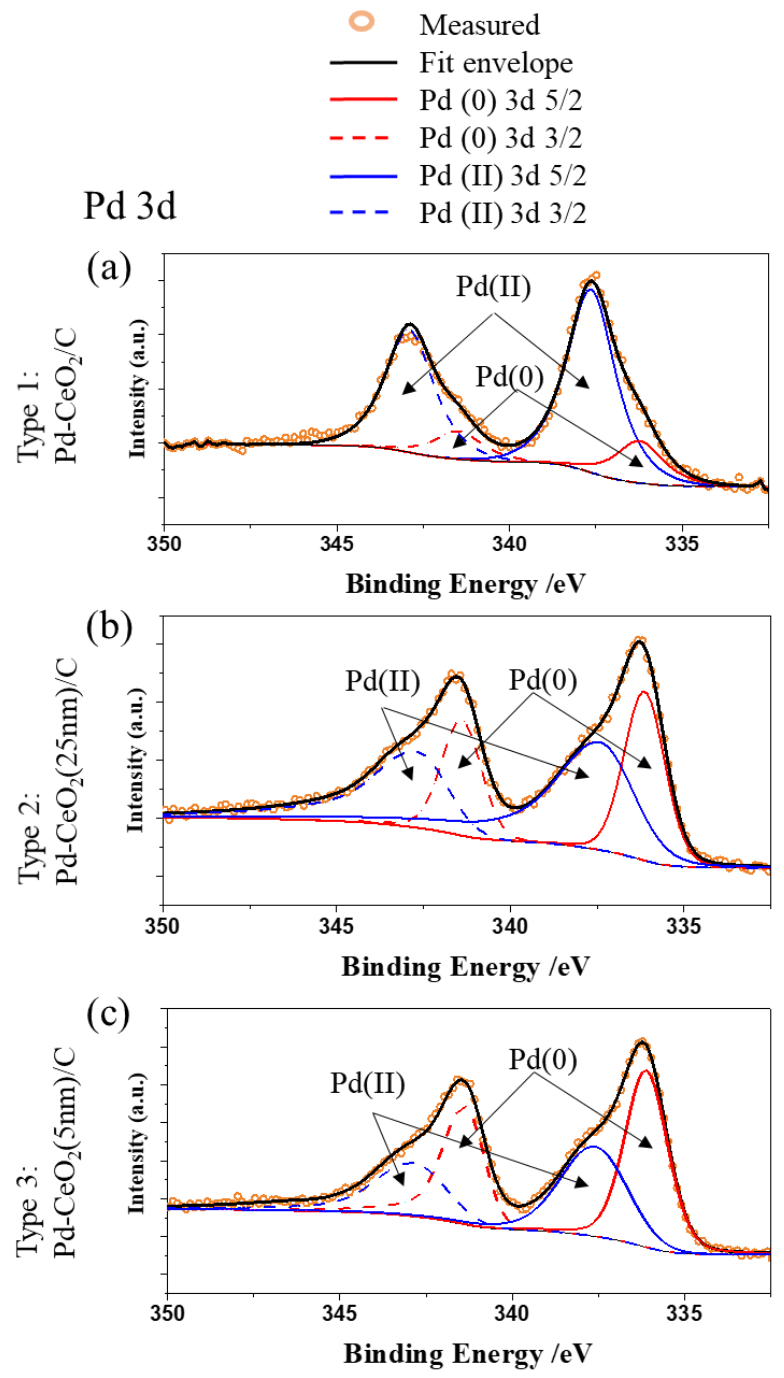

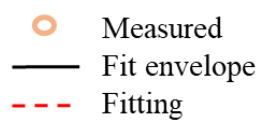

$3 \mathrm{~d} 3 / 2$

Ce (IV) $3 d$

(d)

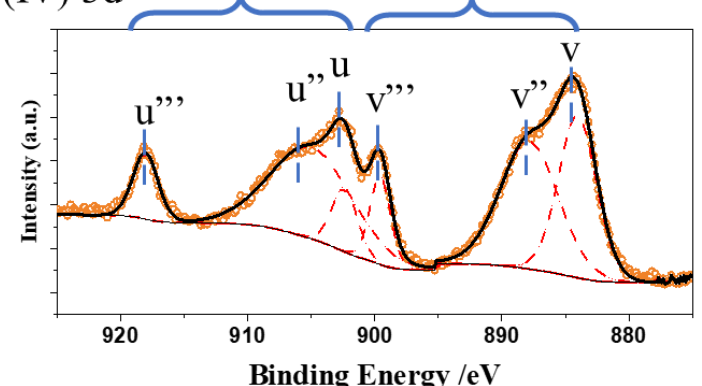

(e)

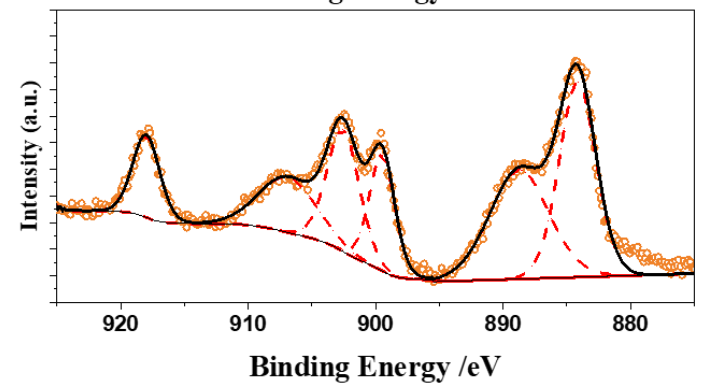

(f)

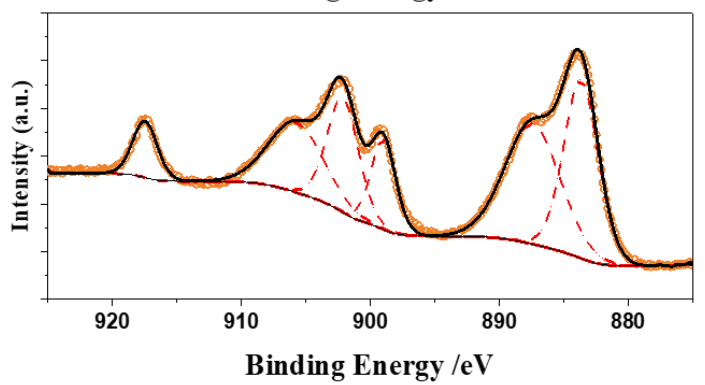

Figure 4. (a-c) X-ray photoelectron spectra for Pd 3d region; (d-f) Ce 3d region for three types of Pd$\mathrm{CeO}_{2} / \mathrm{C}$ catalysts.

Figure 4a-c shows the high-resolution Pd 3d photoelectron spectra. Due to spin-orbit coupling, the Pd 3d spectra are split into two peaks of $3 \mathrm{~d} 5 / 2$ and $3 \mathrm{~d} 3 / 2$ core electrons, respectively. Two pairs of peaks are fitted to the spectra, representing two Pd species. The pair at lower binding energy can be assigned to metallic Pd species, while the pair at higher binding energy can be assigned to Pd (II) species. The contribution of metallic Pd and oxidized Pd (II) phases in the catalyst composition is summarized in Table 1. It is worth noting that the reported binding energies for Pd species (Table 1) are higher compared to bulk Pd or PdO [45]. It has been shown that small nanoparticles result in higher binding energy due to the screening effect of core holes and lattice strains [46-48]. Therefore, we assigned the two binding energies to metallic $\mathrm{Pd}$ and $\mathrm{Pd}$ (II) rather than higher valence $\mathrm{Pd}$ species. The $\mathrm{Pd}(\mathrm{II}) / \mathrm{Pd}(0)$ ratio is significantly higher for Type 1 catalysts (82/18) compared to the Type $2(59 / 41)$ and 3 (47/53) composites. This is in a good agreement with the microscopic observations discussed earlier. Type 1 catalyst has more homogeneous distribution of $\mathrm{Pd}$ and $\mathrm{CeO}_{2}$ which results in more intimate $\mathrm{Pd}-\mathrm{CeO}_{2}$ chemical interaction (close nanoparticle to nanoparticle interaction) as seen in Figure 3. The high ratio of $\mathrm{Pd}(0)$ in Type 2 and 3 arises from poor homogeneity: $\mathrm{Pd}$ segregates on the surface of $\mathrm{CeO}_{2}$ particles and thus the surface of $\mathrm{Pd}$ shows higher composition of metallic $\mathrm{Pd}(0)$. To provide further evidence to the effect of $\mathrm{Pd}^{-\mathrm{CeO}_{2}}$ interaction on $\mathrm{Pd}(\mathrm{II}) / \mathrm{Pd}(0)$ ratio, we analyzed Pd supported on carbon catalyst synthesized with RSDT 
process in Figure $\mathrm{S} 1$ (Supplementary Information). Without $\mathrm{CeO}_{2}$ phase in the catalyst, the composition of Pd (0) increased to $~ 70 \%$, while a $30 \%$ of Pd (II) species remains on Pd surface. Although the $\mathrm{Pd}$ nanoparticles produced from RSDT process exhibit a partially oxidized surface, incorporating the $\mathrm{CeO}_{2}$ phase in the catalyst increases the Pd (II) composition on the surface, suggesting a change of the Pd electronic structure with $\mathrm{CeO}_{2}$ interactions.

The high-resolution Ce 3d photoelectron spectra are shown in Figure 4d-f. Deconvolution of the spectra suggests that the Ce (IV) is the predominate species and fitting with additional Ce (III) species did not result in a better fitting agreement of the experimental curve. The binding energies labeled v, v", v"' are attributed to spin-orbit coupling of 3d5/2 core electrons and $\mathrm{u}, \mathrm{u}$ ", $\mathrm{u}$ "' are attributed to spin-orbit coupling of $3 \mathrm{~d} 3 / 2$ core electrons [49,50]. It is noted that the Ce spectra for Type 2 catralyst require an extra peak at $\sim 880 \mathrm{eV}$ in order for a complete agreement between the fitting envelope and the experimental data. This extra peak is verified to be the Auger peak of fluorine $\left(\mathrm{F} \mathrm{KL}_{1} \mathrm{~L}_{1}\right)$ with a $\mathrm{Pd} / \mathrm{C}$ sample (Figure $\mathrm{S} 1$ ) without $\mathrm{CeO}_{2}$ support and the fluorine stems from the Nafion ${ }^{\circledR}$ binder in the catalyst layer. Ignoring the $\mathrm{F} \mathrm{KL}_{1} \mathrm{~L}_{1}$ peak does not deteriorate the quality of data fitting. Thus, we conclude that the Ce phase for all three types of catalyst are mainly $\mathrm{CeO}_{2}$ species.

Table 1 Compositions and positions of $\mathrm{Pd}$ species for three types of $\mathrm{Pd}-\mathrm{CeO}_{2} / \mathrm{C}$ catalysts

\begin{tabular}{|c|c|c|c|c|c|c|}
\hline Sample ID & $\begin{array}{l}\text { Palladium } \\
\text { species }\end{array}$ & $\begin{array}{c}\text { Percentage, } \\
\%\end{array}$ & $\begin{array}{c}5 / 2 \text { position, } \\
\mathrm{eV}\end{array}$ & $\begin{array}{c}\text { 3/2 position, } \\
\text { eV }\end{array}$ & Line shape & $\begin{array}{c}\text { FWHM, } \\
\text { eV }\end{array}$ \\
\hline \multirow{2}{*}{ 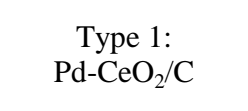 } & $\operatorname{Pd}(0)$ & 18 & 336.2 & 341.4 & GL(80) & 1.64 \\
\hline & Pd (II) & 82 & 337.6 & 342.8 & GL(80) & 1.94 \\
\hline \multirow{2}{*}{ 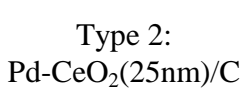 } & $\operatorname{Pd}(0)$ & 41 & 336.1 & 341.4 & GL(89) & 1.38 \\
\hline & Pd (II) & 59 & 337.4 & 342.7 & GL(83) & 2.66 \\
\hline \multirow{2}{*}{ 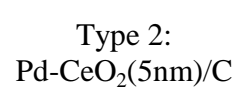 } & $\operatorname{Pd}(0)$ & 53 & 336.1 & 341.4 & GL(80) & 1.47 \\
\hline & Pd (II) & 47 & 337.6 & 342.8 & GL(100) & 2.65 \\
\hline
\end{tabular}

To further reveal the effect of the microscopic morphology and the surface oxidation state of $\mathrm{Pd}-\mathrm{CeO}_{2} / \mathrm{C}$ composites on the $\mathrm{HOR}$ kinetics, the electrochemical properties of $\mathrm{Pd}-\mathrm{CeO}_{2} / \mathrm{C}$ catalysts were characterized in $0.1 \mathrm{M} \mathrm{NaOH}$ electrolyte at room temperature (Figure 5). Cyclic voltammograms (CV) of $\mathrm{Pd}-\mathrm{CeO}_{2} / \mathrm{C}$ catalysts are shown in Figure 5a. Noticeably, the CVs on the composite materials significantly differ from the ones recorded on metallic Pd in alkaline media [19]. The peak of PdO electroreduction [19] is suppressed in $\mathrm{Pd}-\mathrm{CeO}_{2} / \mathrm{C}$ catalysts (Figure 5a), which complicates the electrochemical surface area assessment. Broad peaks appear in the potential window of 0.1-0.6 V vs. RHE can be attributed to $\mathrm{H}$ adsorption/desorption process to which both $\mathrm{Pd}$ and $\mathrm{CeO}_{2}$ contribute [28,35]. The $\mathrm{H}$ desorption for $\mathrm{Pd}$ occurs at lower potential than $\mathrm{CeO}_{2}$ [35]. The insert of Figure 5a shows enlarged CV of Type 1 and 2. The $\mathrm{H}$ desorption for $\mathrm{Pd}$ and $\mathrm{CeO}_{2}$ can be distinguished in the $\mathrm{CV}$ of Type 1, while Type 2 shows mainly the $\mathrm{H}$ desorption for $\mathrm{Pd}$. It is noted that the Type 3 catalyst shows a more pronounced anodic peak than the other two types of catalysts in this potential region, which is likely due to the small $\mathrm{CeO}_{2}$ particle size and high $\mathrm{CeO}_{2}$ loading (Table S2) offering higher surface area than Type 1 and 2. 
(a)

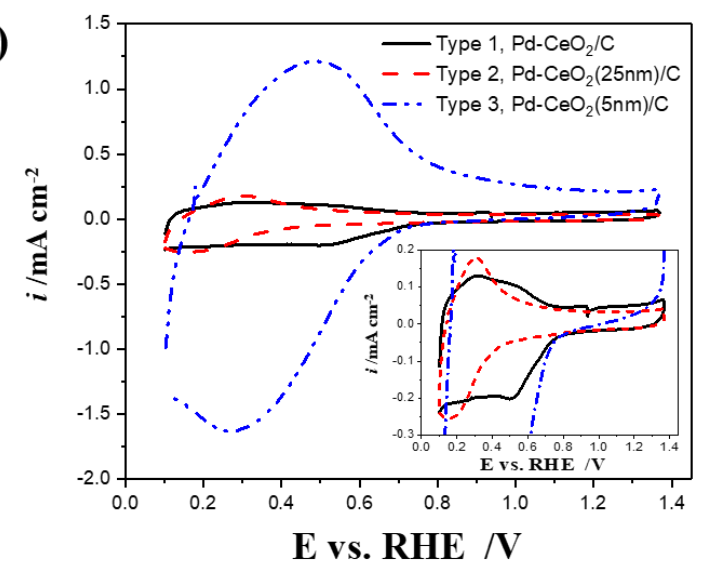

(c)

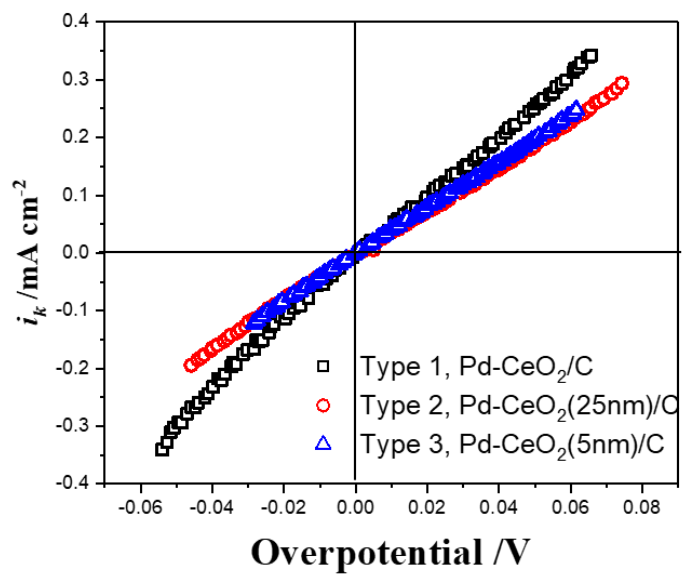

(b)

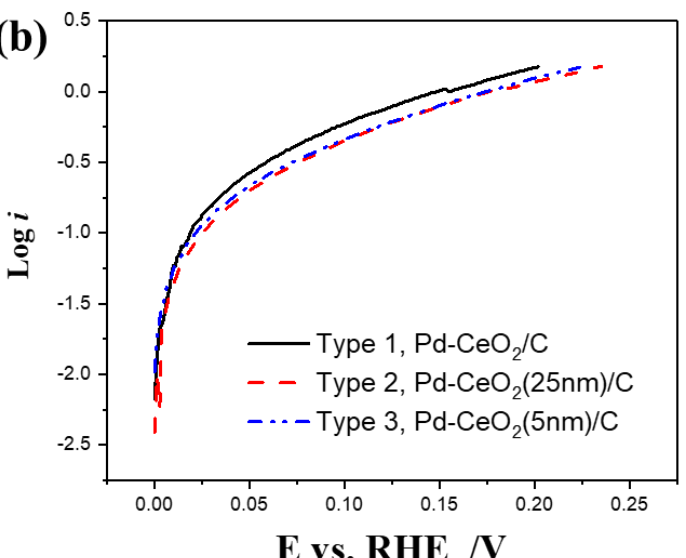

(d)

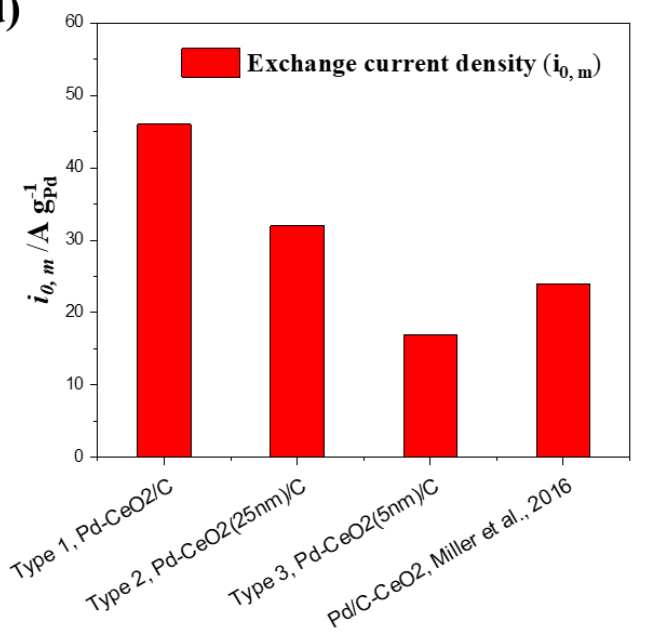

Figure 5. (a) Cyclic voltammograms of three types of $\mathrm{Pd}_{-} \mathrm{CeO}_{2} / \mathrm{C}$ catalysts $\left(\mathrm{N}_{2}\right.$-purged $0.1 \mathrm{M} \mathrm{NaOH}$ at room temperature, $50 \mathrm{mV} \mathrm{s}^{-1}$ ). Insert in (a) shows an enlarged figure of Type 1 and 2. (b) Tafel plots of the HOR polarization curves for three types of $\mathrm{Pd} / \mathrm{CeO}_{2} / \mathrm{C}$ catalysts $\left(\mathrm{H}_{2}\right.$-purged $0.1 \mathrm{M} \mathrm{NaOH}$ at room temperature, $10 \mathrm{mV} \mathrm{s}^{-1}$ ). (c) Micropolarization region to extrapolate the exchange current densities. (d) Mass-normalized exchange current densities for three types of RSDT-derived $\mathrm{Pd}-\mathrm{CeO}_{2} / \mathrm{C}$ catalysts compared with the state-of-the-art $\mathrm{Pd}-\mathrm{CeO}_{2} / \mathrm{C}$ electrocatalyst. [28]

Tafel plots (Figure 5b) show that Type 1 has higher HOR performance than Type 2 and 3 in the wide range of potentials $(0.0-0.25 \mathrm{~V})$. Numerically the HOR activity values were compared by the magnitude of mass specific exchange current $\left(i_{0}\right)$. The exchange current was calculated using the micropolarization approach [20,51] where the Butler-Volmer equation is approximated to a linear equation $i_{k}=i_{0} \frac{F \eta}{R T}$ in a narrow overpotential range, where $i_{\mathrm{k}}$ is the kinetic current, $i_{0}$ is the exchange current, $\eta$ is the overpotential, $F$ is the Faraday constant $\left(96485 \mathrm{C} \mathrm{mol}^{-1}\right), R$ is the gas constant $\left(8.413 \mathrm{~J} \mathrm{~mol}^{-1} \mathrm{~K}^{-1}\right)$, and $T$ is the temperature $(\mathrm{K})$. Figure $5 \mathrm{c}$ compared the HOR polarization curves in the micropolarization range. The resulting exchange current density values normalized to the Pd loading are plotted in Figure 5d.

The HOR activity for RSDT-derived catalysts follows the trend of Type $1>$ Type $2>$ Type 3 . This trend corroborates well with the degree of Pd oxidation state ( $\mathrm{Pd}(\mathrm{II}) / \mathrm{Pd}(0)$ ratio) obtained using XPS (Table 1), which in turn is in a good agreement with the elemental maps of $\mathrm{Pd}$ and $\mathrm{Ce}$ (Figure 3). The $\mathrm{Pd}-\mathrm{CeO}_{2}$ chemical interaction results in partial charge transfer from metallic $\mathrm{Pd}$ atoms to $\mathrm{CeO}_{2}$ particles and thus, 
higher concentration of $\mathrm{Pd}$ (II) suggests stronger interaction of $\mathrm{Pd}$ and $\mathrm{CeO}_{2}$ [28]. According to the current understanding of the HOR kinetics on Pt [52], Ir [52], Pd [19,38] and Ni[53], the rate-determining step (RDS) of HOR in alkaline media is the Volmer step[19]:

$\mathrm{H}_{\mathrm{ad}}+\mathrm{OH}^{-} \leftrightarrow \mathrm{H}_{2} \mathrm{O}+e+*$

A partially oxidized surface enhances the $\mathrm{HOR}$ activity by weakening of metal-H bonding which promote the RDS step (equation 3) $[19,52,54]$. For $\mathrm{Pd}-\mathrm{CeO}_{2} / \mathrm{C}$ catalysts, the $\mathrm{Pd}-\mathrm{CeO}_{2}$ interactions weakens the $\mathrm{Pd}-$ hydrogen bonding and enhances the $\mathrm{OH}^{-}$transfer from the anion conducting ionomer to the active metal surface[29]. Noticeably, the Type 1 and 2 electrocatalysts outperform the state-of-the-art $\mathrm{Pd}-\mathrm{CeO}_{2} / \mathrm{C}$ composite reported previously by Miller et al. [28,29] which confirms the improvement of $\mathrm{Pd}-\mathrm{CeO}_{2}$ interface with RSDT synthesis process. Although a high Pd oxide content of $87 \%$ is reported in [28] with X-ray absorption spectroscopy (XAS), the XPS spectra therein shows a metal-enriched surface. It is likely that an oxide-rich surface, like the Type 1 catalyst, exhibits higher enhancement for HOR, albeit further structural evidence is need for Type 1 catalyst to verify the bulk oxide content.

\section{Conclusions}

In summary, three different types of $\mathrm{Pd}-\mathrm{CeO}_{2} / \mathrm{C}$ catalysts were synthesized using reactive spray deposition technique. The catalysts showed improved chemical interaction between $\mathrm{Pd}$ and $\mathrm{CeO}_{2}$ compared to previous works based on wet chemistry method. The activity of Type 1 and Type 2 electrocatalysts in $\mathrm{HOR}$ in $0.1 \mathrm{M} \mathrm{NaOH}$ exceeds that of the state-of-the-art $\mathrm{Pd}-\mathrm{CeO}_{2} / \mathrm{C}$ composites reported in the literature. The correlation between the $\mathrm{Pd}-\mathrm{CeO}_{2}$ interaction and $\mathrm{HOR}$ activity is established through comparison of XPS analysis of the three types of $\mathrm{Pd}_{-}-\mathrm{CeO}_{2} / \mathrm{C}$ catalysts. Based on the experimental results, the $\mathrm{Pd}-\mathrm{CeO}_{2}$ chemical interaction leads to partial charge transfer from metallic $\mathrm{Pd}$ atoms to $\mathrm{CeO}_{2}$ particles resulting in high concentration of Pd (II) on the catalyst surface. This, in turn, may weaken the Pd-hydrogen bonding energy which promote the rate determining Volmer step of HOR in alkaline media. The RSDT technique has shown its feasibility for the development of $\mathrm{Pd}-\mathrm{CeO}_{2} / \mathrm{C}$ composite HOR catalysts. Further implementation of the RSDT process for the optimization of Pd$\mathrm{CeO}_{2} / \mathrm{C}$ catalyst design should concentrate on obtaining homogeneous composites with the lowest particle sizes, intimate contact between ceria and $\mathrm{Pd}$, and the optimal Pd-to-Ce ratio. Application of these optimized HOR catalysts in AEMFC testing is the subject of ongoing work in our laboratories. The combination of experimental techniques such as STEM, XPS and RDE was shown to be a very powerful instrument in revealing the optimal synthetic approaches and optimal compositions of $\mathrm{Pd}-\mathrm{CeO}_{2} / \mathrm{C}$ composite electrocatalysts.

\section{Acknowledgement}

This work was partially funded by the European Union's Horizon 2020 research and innovation program [grant No. 721065]; by the Ministry of Science, Technology \& Space of Israel through the M.Era-NET Transnational Call 2015, NEXTGAME project [grant No. 3-12940] and through grant No. 3-12948; by the Israel Science Foundation (ISF) [grant No. 1481/17]; by the Ministry of National Infrastructure, Energy and Water Resources of Israel [grant No. 3-13671]. This research was also partially carried out within the framework of the UConn-Technion Energy Collaboration initiative, supported by the Satell Family Foundation, the Maurice G. Gamze Endowed Fund (at the American Technion Society), Larry Pitt and Phillis Meloff, The Eileen and Jerry Lieberman UConn/Israel Global Partnership Fund and the Grand Technion Energy Program (GTEP). The authors would also like to acknowledge the financial support of Melvyn \& Carolyn Miller Fund for Innovation, as well as the support of Planning \& Budgeting Committee / ISRAEL Council for Higher Education (CHE) and Fuel Choice Initiative (Prime Minister Office of ISRAEL), within the framework of "Israel National Research Center for Electrochemical Propulsion (INREP)".

The authors would like to thank Dr. William Willis for assistance in XPS characterization and analysis. The authors would also like to thank Abhinav Poozhikunnath for assistance in TEM characterization. 


\section{Reference List}

[1] J.R. Varcoe, P. Atanassov, D.R. Dekel, A.M. Herring, M.A. Hickner, P.A. Kohl, A.R. Kucernak, W.E. Mustain, K. Nijmeijer, K. Scott, T. Xu, L. Zhuang, Anion-exchange membranes in electrochemical energy systems, Energy Environ. Sci. 7 (2014) 3135-3191.

[2] D.R. Dekel, Alkaline Membrane Fuel Cell (AMFC) Materials and System Improvement - State-ofthe-Art, ECS Transactions. 50 (2013) 2051-2052.

[3] D.R. Dekel, Review of cell performance in anion exchange membrane fuel cells, Journal of Power Sources. 375 (2018) 158-169.

[4] S. Gottesfeld, D.R. Dekel, M. Page, C. Bae, Y. Yan, P. Zelenay, Y.S. Kim, Anion exchange membrane fuel cells: Current status and remaining challenges, Journal of Power Sources. 375 (2018) 170184.

[5] U. Krewer, C. Weinzierl, N. Ziv, D.R. Dekel, Impact of carbonation processes in anion exchange membrane fuel cells, Electrochimica Acta. 263 (2018) 433-446.

[6] N. Ziv, W.E. Mustain, D.R. Dekel, The Effect of Ambient Carbon Dioxide on Anion-Exchange Membrane Fuel Cells, ChemSusChem. 11 (2018) 1136-1150.

[7] N. Ziv, D.R. Dekel, A practical method for measuring the true hydroxide conductivity of anion exchange membranes, Electrochemistry Communications. 88 (2018) 109-113.

[8] C. Lafforgue, M. Chatenet, L. Dubau, D.R. Dekel, Accelerated Stress Test of Pt/C Nanoparticles in an Interface with an Anion-Exchange Membraneâ€”An Identical-Location Transmission Electron Microscopy Study, ACS Catal. 8 (2018) 1278-1286.

[9] D.R. Dekel, M. Amar, S. Willdorf, M. Kosa, S. Dhara, C.E. Diesendruck, Effect of Water on the Stability of Quaternary Ammonium Groups for Anion Exchange Membrane Fuel Cell Applications, Chem. Mater. 29 (2017) 4425-4431.

[10] D.R. Dekel, S. Willdorf, U. Ash, M. Amar, S. Pusara, S. Dhara, S. Srebnik, C.E. Diesendruck, The critical relation between chemical stability of cations and water in anion exchange membrane fuel cells environment, Journal of Power Sources. 375 (2018) 351-360.

[11] C.E. Diesendruck, D.R. Dekel, Water - A key parameter in the stability of anion exchange membrane fuel cells, Current Opinion in Electrochemistry. 9 (2018) 173-178.

[12] S. Pusara, S. Srebnik, D.R. Dekel, Molecular Simulation of Quaternary Ammonium Solutions at Low Hydration Levels, J. Phys. Chem. C. 122 (2018) 11204-11213.

[13] E.S. Davydova, S. Mukerjee, F. Jaouen, D.R. Dekel, Electrocatalysts for Hydrogen Oxidation Reaction in Alkaline Electrolytes, ACS Catal. 8 (2018) 6665-6690.

[14] S.E. Davydova, J. Zaffran, K. Dhaka, C.M. Toroker, R.D. Dekel, Hydrogen Oxidation on Ni-Based Electrocatalysts: The Effect of Metal Doping, Catalysts. 8 (2018). 
[15] L. Gao, Y. Wang, H. Li, Q. Li, N. Ta, L. Zhuang, Q. Fu, X. Bao, A nickel nanocatalyst within a hBN shell for enhanced hydrogen oxidation reactions, Chem. Sci. 8 (2017) 5728-5734.

[16] S. Kabir, K. Lemire, K. Artyushkova, A. Roy, M. Odgaard, D. Schlueter, A. Oshchepkov, A. Bonnefont, E. Savinova, D.C. Sabarirajan, P. Mandal, E.J. Crumlin, I. Zenyuk, P. Atanassov, A. Serov, Platinum group metal-free NiMo hydrogen oxidation catalysts: high performance and durability in alkaline exchange membrane fuel cells, J. Mater. Chem. A. 5 (2017) 24433-24443.

[17] Z. Zhuang, S.A. Giles, J. Zheng, G.R. Jenness, S. Caratzoulas, D.G. Vlachos, Y. Yan, Nickel supported on nitrogen-doped carbon nanotubes as hydrogen oxidation reaction catalyst in alkaline electrolyte, Nature Communications. 7 (2016) 10141.

[18] J. Zheng, S. Zhou, S. Gu, B. Xu, Y. Yan, Size-Dependent Hydrogen Oxidation and Evolution Activities on Supported Palladium Nanoparticles in Acid and Base, Journal of The Electrochemical Society. 163 (2016) F499-F506.

[19] J. Zheng, W. Sheng, Z. Zhuang, B. Xu, Y. Yan, Universal dependence of hydrogen oxidation and evolution reaction activity of platinum-group metals on $\mathrm{pH}$ and hydrogen binding energy, Sci Adv. 2 (2016).

[20] J. Durst, A. Siebel, C. Simon, F. HaschÃ®, J. Herranz, H.A. Gasteiger, New insights into the electrochemical hydrogen oxidation and evolution reaction mechanism, Energy Environ. Sci. 7 (2014) $2255-2260$.

[21] W. Sheng, H.A. Gasteiger, Y. Shao-Horn, Hydrogen Oxidation and Evolution Reaction Kinetics on Platinum: Acid vs Alkaline Electrolytes, Journal of The Electrochemical Society. 157 (2010) B1529B1536.

[22] E.G. Mahoney, W. Sheng, Y. Yan, J.G. Chen, Platinum-Modified Gold Electrocatalysts for the Hydrogen Oxidation Reaction in Alkaline Electrolytes, CHEMELECTROCHEM. 1 (2014) 2058-2063.

[23] S.M. Alia, Y. Yan, Palladium Coated Copper Nanowires as a Hydrogen Oxidation Electrocatalyst in Base, Journal of The Electrochemical Society. 162 (2015) F849-F853.

[24] S. St. John, R.W. Atkinson, K.A. Unocic, R.R. Unocic, T.A. Zawodzinski, A.B. Papandrew, Platinum and Palladium Overlayers Dramatically Enhance the Activity of Ruthenium Nanotubes for Alkaline Hydrogen Oxidation, ACS Catal. 5 (2015) 7015-7023.

[25] M. Alesker, M. Page, M. Shviro, Y. Paska, G. Gershinsky, D.R. Dekel, D. Zitoun, Palladium/nickel bifunctional electrocatalyst for hydrogen oxidation reaction in alkaline membrane fuel cell, Journal of Power Sources. 304 (2016) 332-339.

[26] I. Bakos, A. Paszternák, D. Zitoun, Pd/Ni Synergestic Activity for Hydrogen Oxidation Reaction in Alkaline Conditions, Electrochimica Acta. 176 (2015) 1074-1082.

[27] R. Jervis, N. Mansor, C. Gibbs, C.A. Murray, C.C. Tang, P.R. Shearing, D.J.L. Brett, Hydrogen Oxidation on PdIr/C Catalysts in Alkaline Media, Journal of The Electrochemical Society. 161 (2014) F458-F463. 
[28] H.A. Miller, A. Lavacchi, F. Vizza, M. Marelli, F. Di Benedetto, F. D'Acapito, Y. Paska, M. Page, D.R. Dekel, A Pd/C-CeO2 Anode Catalyst for High-Performance Platinum-Free Anion Exchange Membrane Fuel Cells, Angew. Chem. Int. Ed. 55 (2016) 6004-6007.

[29] H.A. Miller, F. Vizza, M. Marelli, A. Zadick, L. Dubau, M. Chatenet, S. Geiger, S. Cherevko, H. Doan, R.K. Pavlicek, S. Mukerjee, D.R. Dekel, Highly active nanostructured palladium-ceria electrocatalysts for the hydrogen oxidation reaction in alkaline medium, Nano Energy. 33 (2017) 293-305.

[30] T.J. Omasta, X. Peng, H.A. Miller, F. Vizza, L. Wang, J.R. Varcoe, D.R. Dekel, W.E. Mustain, Beyond $1.0 \mathrm{~W} \mathrm{~cm}-2$ Performance without Platinum: The Beginning of a New Era in Anion Exchange Membrane Fuel Cells, Journal of The Electrochemical Society. 165 (2018) J3039-J3044.

[31] A. Trovarelli, Catalysis by Ceria and Related Materials, 1st ed., IMPERIAL COLLEGE PRESS AND DISTRIBUTED BY WORLD SCIENTIFIC PUBLISHING CO, 2002.

[32] H.B. Yu, J. Kim, H. Lee, M.A. Scibioh, J. Lee, J. Han, S.P. Yoon, H.Y. Ha, Development of nanophase $\mathrm{CeO} 2-\mathrm{Pt} / \mathrm{C}$ cathode catalyst for direct methanol fuel cell, Journal of Power Sources. 140 (2005) 59-65.

[33] Q. Tang, Z. Mao, S. Ma, K. Huang, Enhanced methanol oxidation and CO tolerance using CeO2added eggshell membrane-templated Pd network electrocatalyst, RSC Adv. 2 (2012) 11465-11471.

[34] C. Xu, P.K. Shen, Novel Pt/CeO2/C catalysts for electrooxidation of alcohols in alkaline media, Chem. Commun. (2004) 2238-2239.

[35] V. Bambagioni, C. Bianchini, Y. Chen, J. Filippi, P. Fornasiero, M. Innocenti, A. Lavacchi, A. Marchionni, W. Oberhauser, F. Vizza, Energy Efficiency Enhancement of Ethanol Electrooxidation on $\mathrm{Pd}-\mathrm{CeO} / \mathrm{C}$ in Passive and Active Polymer Electrolyte-Membrane Fuel Cells, ChemSusChem. 5 (2012) 1266-1273.

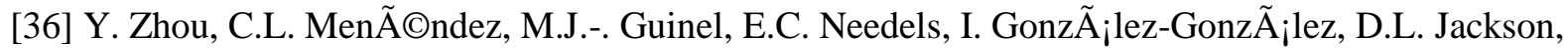
N.J. Lawrence, C.R. Cabrera, C.L. Cheung, Influence of nanostructured ceria support on platinum nanoparticles for methanol electrooxidation in alkaline media, RSC Adv. 4 (2014) 1270-1275.

[37] S. Gil, M. Garcia-Vargas, F.L. Liotta, G. Pantaleo, M. Ousmane, L. Retailleau, A. Giroir-Fendler, Catalytic Oxidation of Propene over Pd Catalysts Supported on CeO2, TiO2, Al2O3 and M/Al2O3 Oxides ( $\mathrm{M}=\mathrm{Ce}, \mathrm{Ti}, \mathrm{Fe}, \mathrm{Mn})$, Catalysts. 5 (2015).

[38] P.L. Cabot, E. Guezala, J.C. Calpe, M.T. García, J. Casado, Application of Pd-Based Electrodes as Hydrogen Diffusion Anodes in Alkaline Fuel Cells, Journal of The Electrochemical Society. 147 (2000) 43-49.

[39] J.M. Roller, S. Kim, T. Kwak, H. Yu, R. Maric, A study on the effect of selected process parameters in a jet diffusion flame for Pt nanoparticle formation, J. Mater. Sci. 52 (2017) 9391-9409.

[40] J.M. Roller, R. Maric, A Study on Reactive Spray Deposition Technology Processing Parameters in the Context of Pt Nanoparticle Formation, J. Therm. Spray Technol. 24 (2015) 1529-1541. 
[41] H. Yu, A. Baricci, A. Casalegno, L. Guetaz, L. Bonville, R. Maric, Strategies to mitigate Pt dissolution in low Pt loading proton exchange membrane fuel cell: II. A gradient Pt loading design, Electrochimica Acta. 247 (2017) 1169-1179.

[42] H. Yu, A. Baricci, A. Bisello, A. Casalegno, L. Guetaz, L. Bonville, R. Maric, Strategies to mitigate Pt dissolution in low Pt loading proton exchange membrane fuel cell: I. A gradient Pt particle size design, Electrochimica Acta. 247 (2017) 1155-1168.

[43] H. Yu, J.M. Roller, W.E. Mustain, R. Maric, Influence of the ionomer/carbon ratio for low-Pt loading catalyst layer prepared by reactive spray deposition technology, J. Power. Sources. 283 (2015) 84-94.

[44] H. Yu, J.M. Roller, S. Kim, Y. Wang, D. Kwak, R. Maric, One-step deposition of catalyst layers for high temperature proton exchange membrane fuel cells (PEMFC), J. Electrochem. Soc. 161 (2014) F622F627.

[45] C.D. Wagner, W.M. Riggs, L.E. Davis, J.F. Moulder, G.E. Muilenberg, in: Anonymous Handbook of X-Ray Photoelectron Spectroscopy, Perkin-Elmer Corporation, Eden Prairie, Minnesota, 1979, pp. 111.

[46] M.G. Mason, L.J. Gerenser, S.-. Lee, Electronic Structure of Catalytic Metal Clusters Studied by XRay Photoemission Spectroscopy, Phys. Rev. Lett. 39 (1977) 288-291.

[47] M.G. Mason, Electronic structure of supported small metal clusters, Phys. Rev. B. 27 (1983) 748762.

[48] W.P. Zhou, A. Lewera, R. Larsen, R.I. Masel, P.S. Bagus, A. Wieckowski, Size Effects in Electronic and Catalytic Properties of Unsupported Palladium Nanoparticles in Electrooxidation of Formic Acid, J Phys Chem B. 110 (2006) 13393-13398.

[49] Y. Zhou, C.L. MenÃ@ndez, M.J.-. Guinel, E.C. Needels, I. GonzÃ $¡ l e z-G o n z \tilde{A} ; l$ lez, D.L. Jackson, N.J. Lawrence, C.R. Cabrera, C.L. Cheung, Influence of nanostructured ceria support on platinum nanoparticles for methanol electrooxidation in alkaline media, RSC Adv. 4 (2014) 1270-1275.

[50] J.C. CONESA, M. FERN?NDEZ-GARC?A, A. MART?NEZ-ARIAS, STUDIES OF CERIACONTAINING CATALYSTS USING MAGNETIC RESONANCE AND X-RAY SPECTROSCOPIES, in: Anonymous Catalysis by Ceria and Related Materials, PUBLISHED BY IMPERIAL COLLEGE PRESS AND DISTRIBUTED BY WORLD SCIENTIFIC PUBLISHING CO, 2002, pp. 169-216.

[51] P.J. Rheinländer, J. Herranz, J. Durst, H.A. Gasteiger, Kinetics of the Hydrogen Oxidation/Evolution Reaction on Polycrystalline Platinum in Alkaline Electrolyte Reaction Order with Respect to Hydrogen Pressure, Journal of The Electrochemical Society. 161 (2014) F1448-F1457.

[52] D. Strmcnik, M. Uchimura, C. Wang, R. Subbaraman, N. Danilovic, d.V. van, A.P. Paulikas, V.R. Stamenkovic, N.M. Markovic, Improving the hydrogen oxidation reaction rate by promotion of hydroxyl adsorption, Nature Chemistry. 5 (2013) 300.

[53] A.G. Oshchepkov, A. Bonnefont, V.N. Parmon, E.R. Savinova, On the effect of temperature and surface oxidation on the kinetics of hydrogen electrode reactions on nickel in alkaline media, Electrochimica Acta. 269 (2018) 111-118. 
[54] Y. Wang, G. Wang, G. Li, B. Huang, J. Pan, Q. Liu, J. Han, L. Xiao, J. Lu, L. Zhuang, Ptâ€“Ru catalyzed hydrogen oxidation in alkaline media: oxophilic effect or electronic effect? Energy Environ. Sci. 8 (2015) 177-181. 


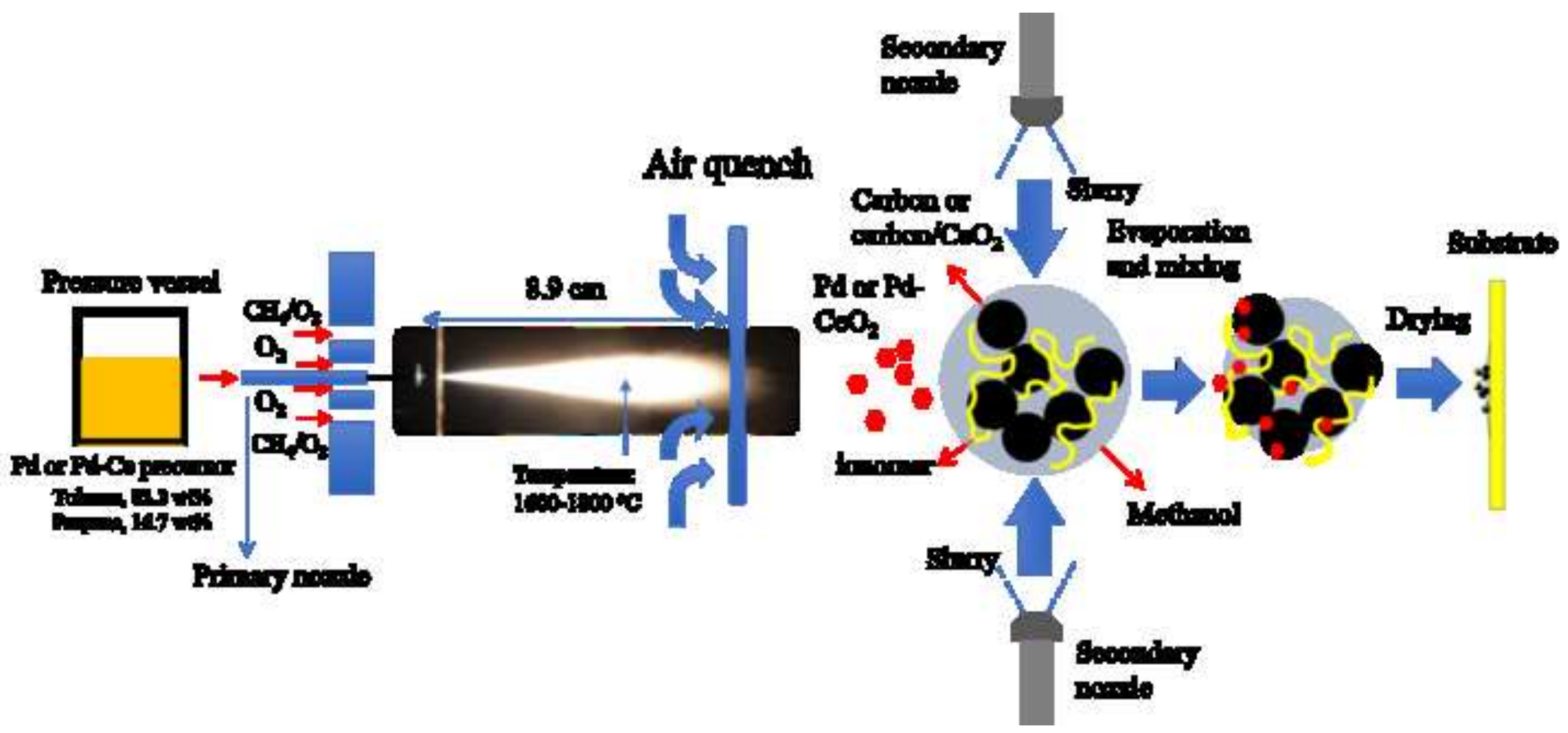




\section{Primary nopilo Secondary noreids}

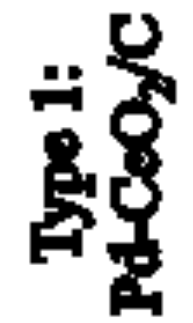

PaCaOn:

2-5 mon

$\bullet$

Pd 2 nm

$\mathbf{P d} \sim \mathbf{2} \mathbf{n m}$

$\bullet$
Carbon $40-80 \mathrm{~nm}$
Cotalyists
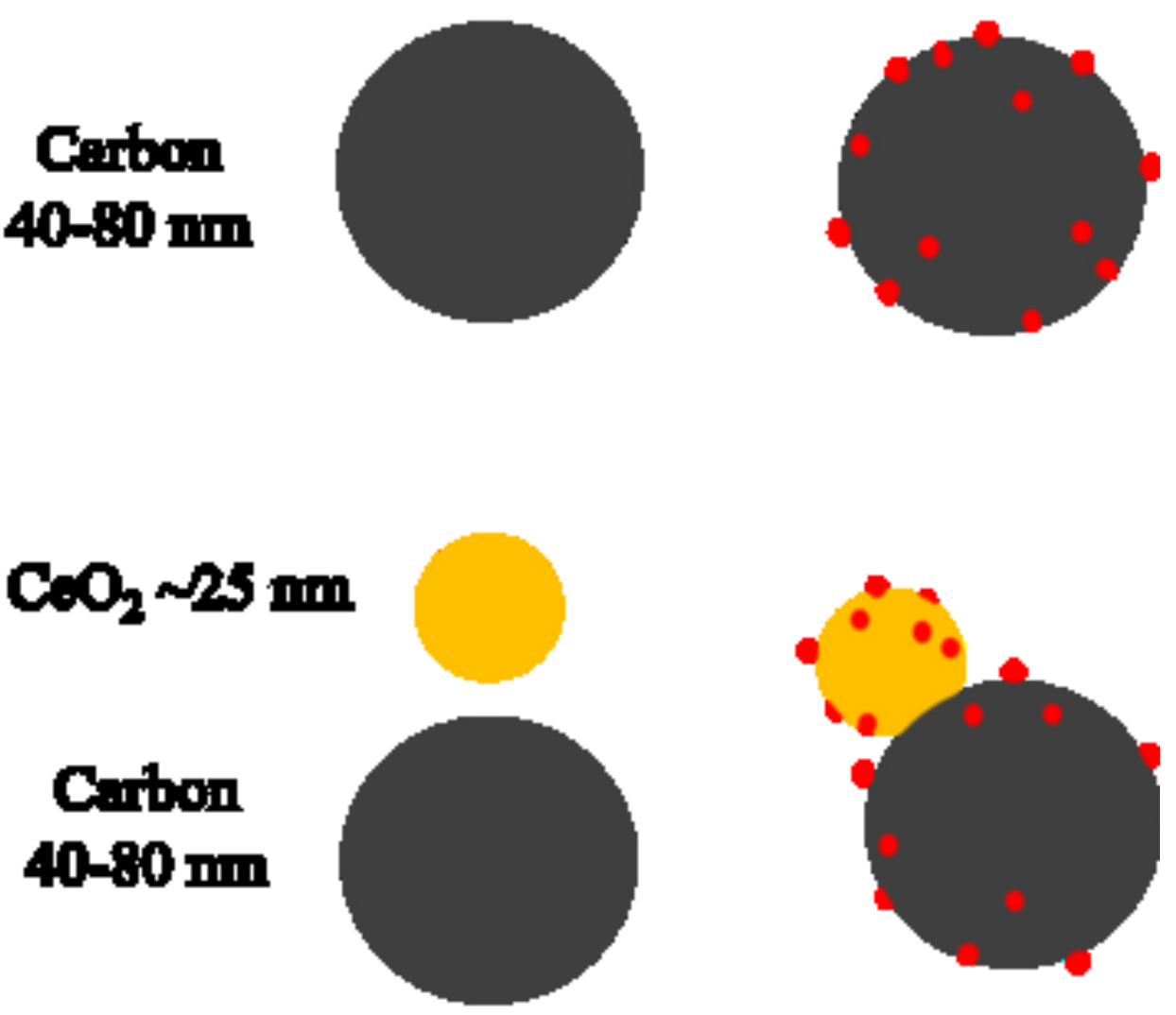

$\mathrm{CeO}_{2} \sim 5 \mathrm{~mm}$

Cerbon 40-80 $\mathrm{mm}$
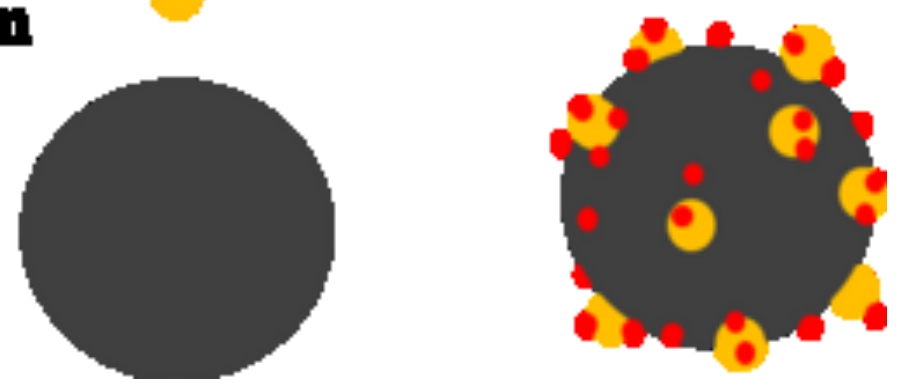
Click here to download high resolution image

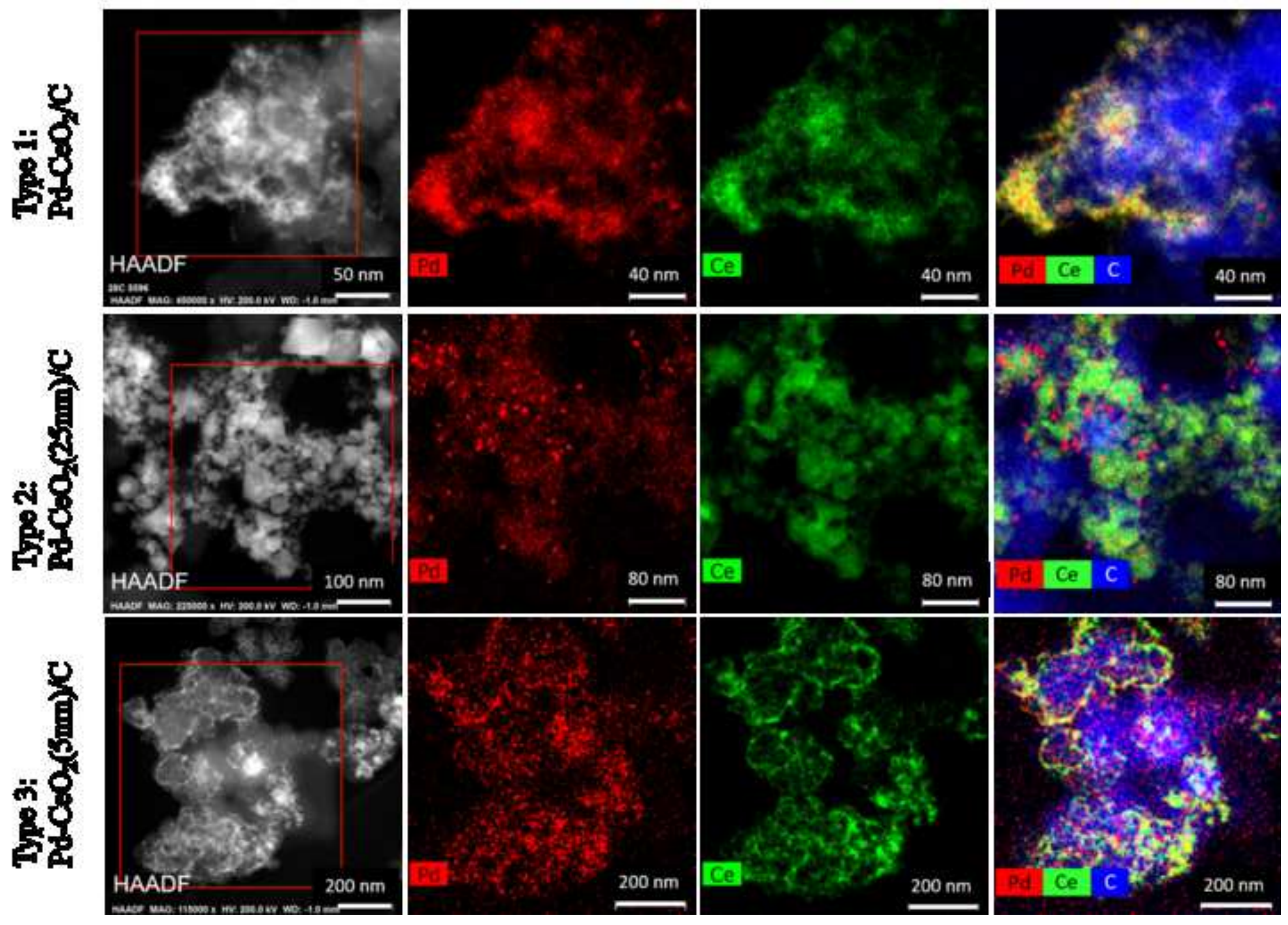

昰

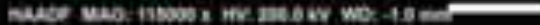



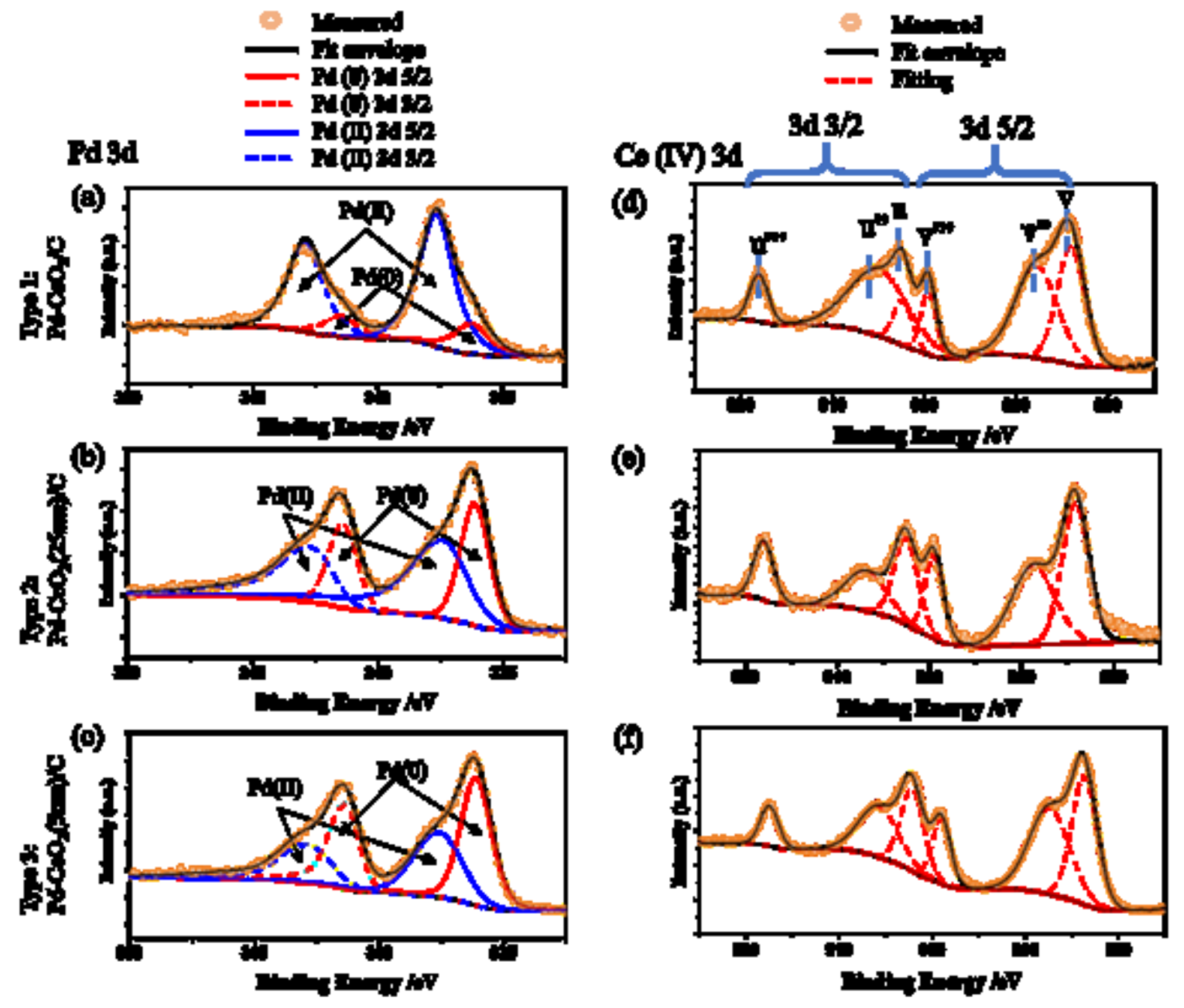
(a)

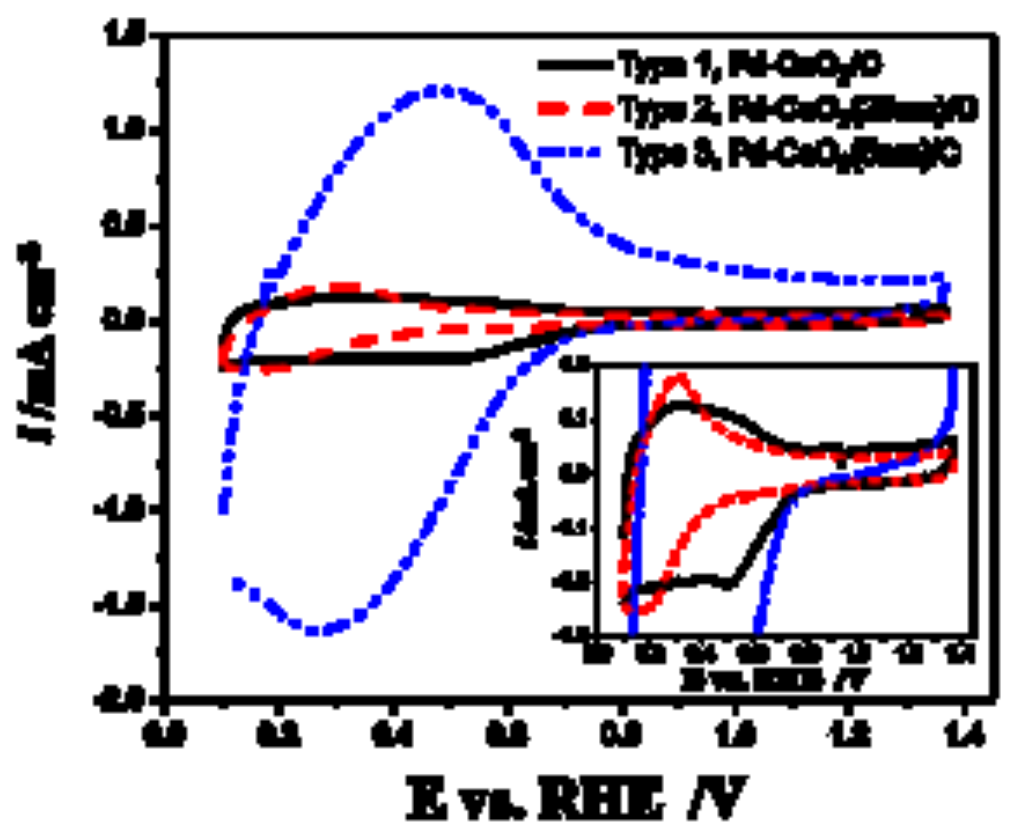

(c)

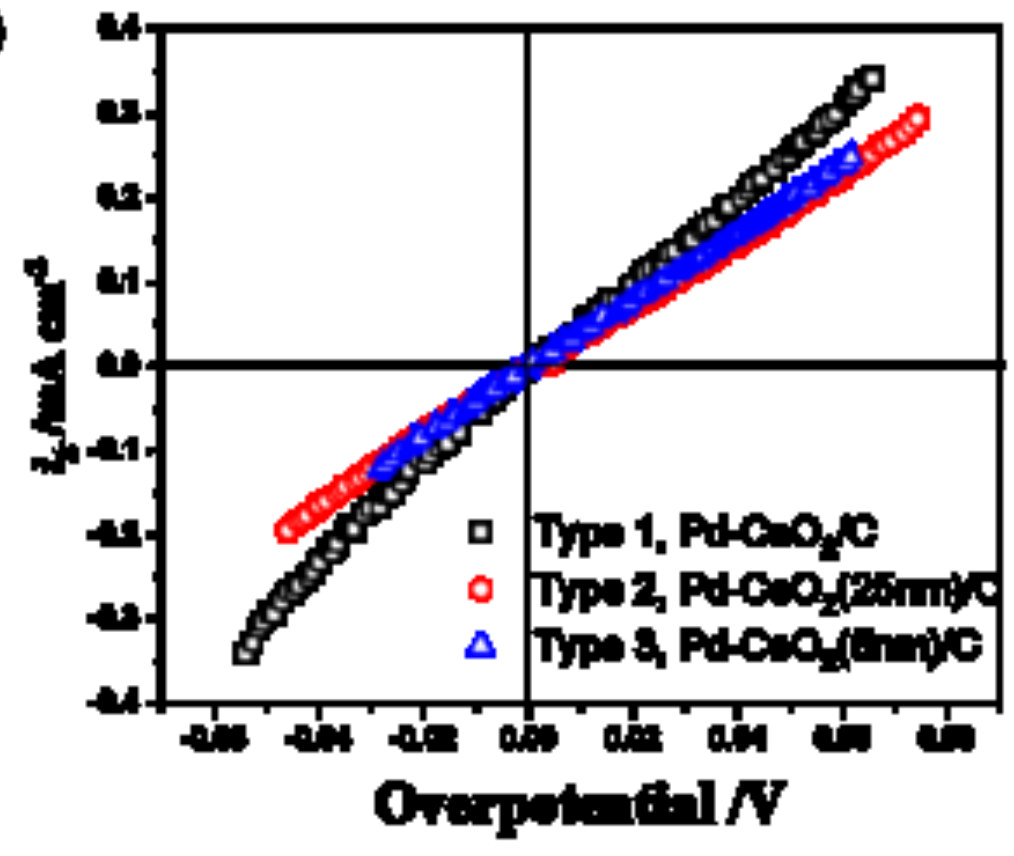

(b)

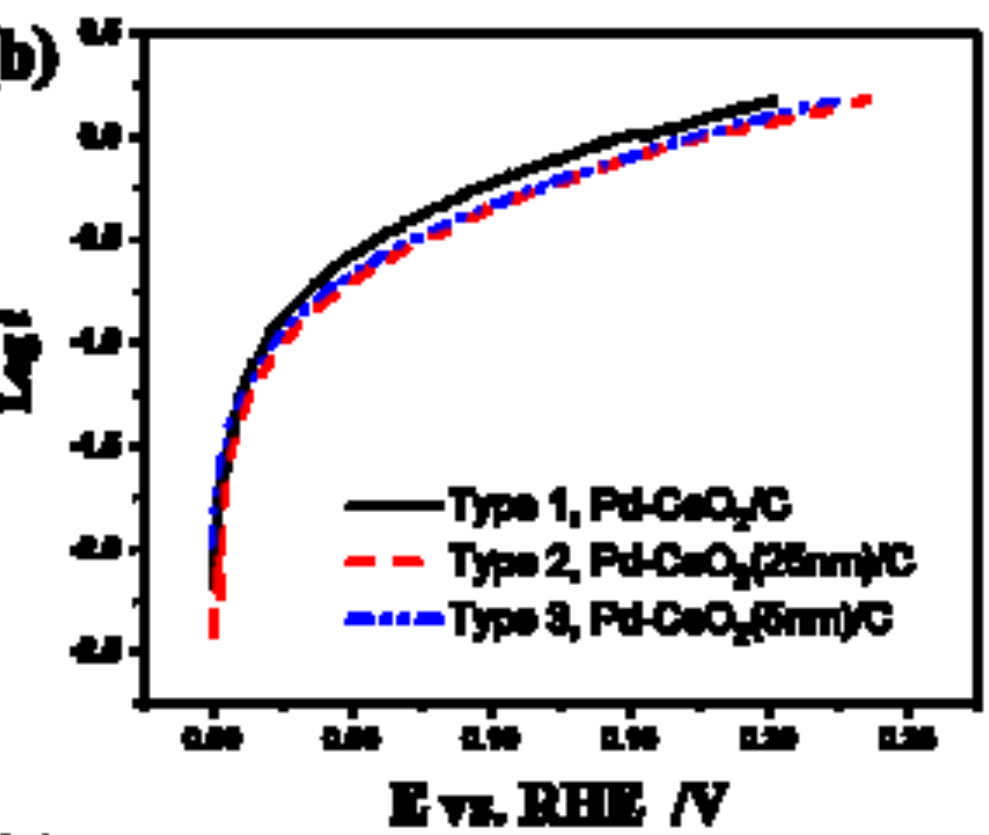

(d)

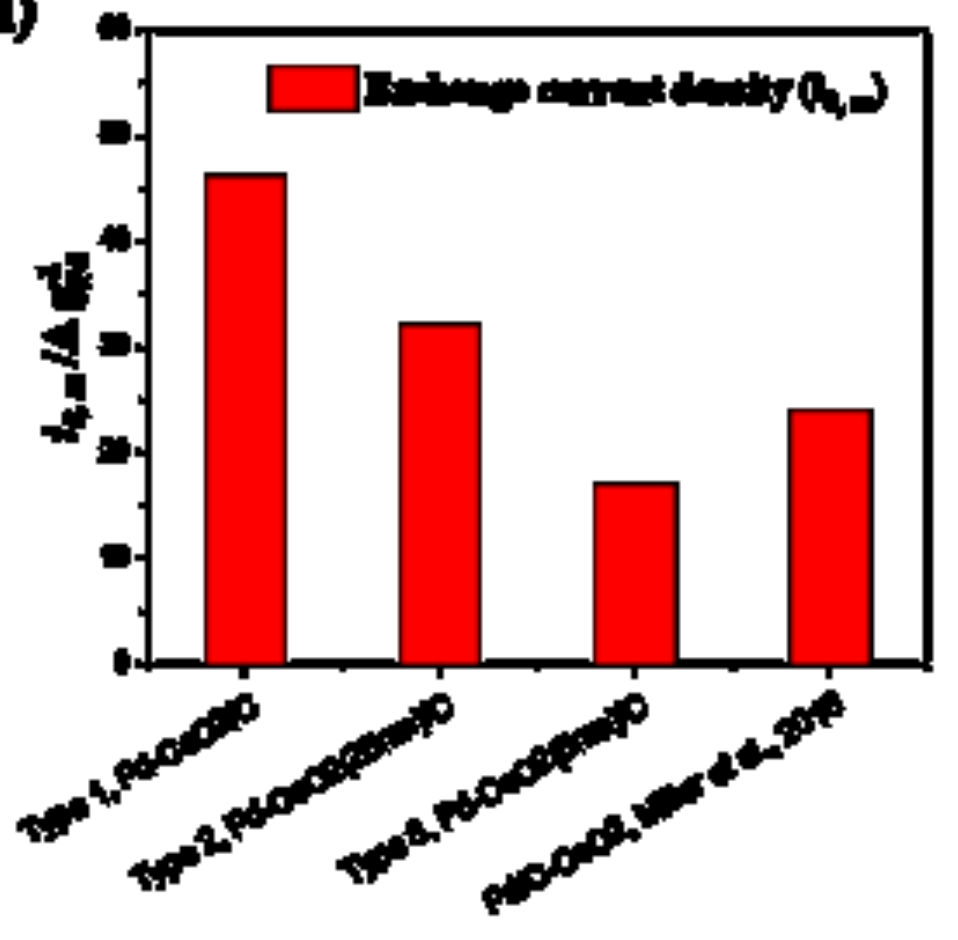



Supporting Information
Click here to download Supporting Information: Supplementary information.docx

Supporting Information
Click here to download Supporting Information: Supplementary information.docx Click here to download Supporting lntormation: Supplementary intormation.docx

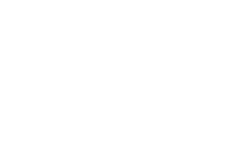

(1)

$\sqrt{3}$

(1)

(1)

. (1) (1) . . . . . . . . . . . . . . 
